\title{
Mercury in seabird feathers: Insight on dietary habits and evidence for exposure levels in the western Indian Ocean
}

\author{
Jessica Kojadinovic ${ }^{a, b, c}$, Paco Bustamante ${ }^{a,{ }^{*}}$, \\ Carine Churlaud $^{d}$, Richard P. Cosson ${ }^{b}$ and Matthieu Le Corre ${ }^{c}$
}

${ }^{a}$ CRELA, UMR 6217, CNRS-IFREMER-Universit'e de La Rochelle, 22 avenue Michel Crépeau, La Rochelle, F17042 France

${ }^{\mathrm{b}}$ Université de Nantes, EMI, EA 2663, 2 rue de la Houssinière, Nantes cedex 3, F-44322 France

' Université de La Réunion, ECOMAR, EA 33, 15 avenue René Cassin, Saint Denis, F-97715 France

d CCA, Université de La Rochelle, 5 Perspective de l'Océan, La Rochelle Cedex 9 F-17 071, France

*: Corresponding author : mailto:paco.bustamante@univ-Ir.fr

\begin{abstract}
:
Breast feathers were used to estimate mercury levels in six marine birds nesting in the tropical western Indian Ocean, i.e. Sooty Tern (Sterna fuscata), Brown Noddy (Anous stolidus), Lesser Noddy (Anous tenuirostris), Audubon Shearwater (Puffinus Iherminieri bailloni), Barau's Petrel (Pterodroma baraui) and the White-tailed Tropicbird (Phaethon lepturus). Juveniles consistently showed lower plumage mercury than adults. The lowest mean level was noted in juvenile Sooty Terns from the Glorioso Archipelago $(0.05 \mu \mathrm{g} g-1)$. The highest levels were obtained for adult Barau's Petrels from Reunion Island $(0.96 \mu \mathrm{g} \mathrm{g}-1)$. An inter-site analysis of Sooty Tern showed higher mercury levels in birds nesting on Juan de Nova Island. Levels were low in comparison with values reported in the plumage of seabirds worldwide. The potential impacts of the size, the type (fish/cephalopod) and the origin (epi-/meso-pelagic) of prey on mercury intake in birds are discussed. Although the diet composition of individuals within a species appeared to be quite variable, combining results on mercury levels with common knowledge of each species allowed additional information on their dietary and foraging habits to be unraveled.
\end{abstract}

Keywords: Marine birds; Trophic ecology; Mercury; Bioaccumulation; Contamination; Tropical islands 


\section{Introduction}

Seabirds are a major component of tropical oceanic environments. Yet, knowledge of tropical seabirds in general, and of their trophic ecology in particular, is still lacking. This is particularly obvious in the tropical western Indian Ocean, home to many avian species that breed on very dispersed islands, forming large colonies sometimes numbering hundreds of thousands of pairs (Le Corre and Jaquemet, 2005). This lack of knowledge may be attributed in part to the logistical difficulties involved in studying animals that scatter over huge areas. Consequently, most knowledge of feeding ecology obtained by conventional methods is restricted to the bird's breeding season because sightings usually occur close to islands and stomach contents (generally obtained at the colony) only gives information on the seabird's last meal. Global Positioning System (GPS) satellite tracking methods, however, have recently been used to investigate the foraging ecology of non-breeding birds (Weimerskirch et al., 2005a).

Because of its bioaccumulation specificities, the analysis of mercury $(\mathrm{Hg})$ in the tissues of seabirds and their prey is a useful technique to complement conventional studies. Mercury levels in an organism depend on a certain number of factors such as its species, its size and the type (fish/cephalopod), the size and/or the origin (demersal vs. pelagic or epi- vs. meso-pelagic) of its prey (Monteiro et al., 1996; Stewart et al., 1997b; Monteiro et al., 1998; Becker et al., 2002; na et al., 2002; Bustamante et al., 2006). Interpreting mercury levels in birds with respect to these factors may offer clues to the birds' principal dietary mercury sources and hence provide information on their dominant prey. Mercury is also the only metal known to be clearly biomagnified in the food chain (Atwell et al., 1998). Its determination in seabirds also serves as reference for environmental contamination monitoring as seabirds are considered as good bioindicators of mercury levels in the marine environment (Furness et al., 1993).

Many studies of mercury in marine birds rely on the use of feathers (e.g. Doi et al., 1984; Burger et al., 1992; Thompson et al., 1993). The non-invasive sampling of feathers allows them to be used for the study of threatened or endangered species, permits the sampling of large numbers of birds, and enables repeated sampling from the same individual over many years. During feather formation, mercury present in the blood and mercury mobilized from various tissues such as liver or kidneys (essentially methyl mercury) is sequestered in the growing feathers, where it binds to sulfhydryl groups of keratin (Goede and De Bruin, 1984; Burger, 1993). Once the feather is formed, the blood ir-

\footnotetext{
* Corresponding author. Tel : +(33) 546507625.

Email address: paco.bustamante@univ-lr.fr (Paco Bustamante).
} 
rigation subsides implying that no further metal can be deposited. Therefore, feathers remain as a record of exposure during the months preceding feather growth. Body feathers and wing coverts are the major elimination routes for mercury in the plumage (Lewis and Furness, 1991). Breast feathers, that will be used in this study, are particularly interesting because they do not reflect molt sequence as do flight feathers. Furthermore, they represent the plumage as a whole and usually show low variability in mercury levels providing the best approximation of the bird's exposure (Lewis et al., 1993; Burger and Gochfeld, 2001a).

This investigation is based on the use of breast feathers to estimate mercury levels in six marine birds inhabiting the tropical western Indian Ocean, viz. the Sooty Tern (Sterna fuscata), the Brown Noddy (Anous stolidus), the Lesser Noddy (Anous tenuirostris), Audubon's Shearwater (Puffinus lherminieri bailloni), Barau's Petrel (Pterodroma baraui) and the White-tailed Tropicbird (Phaethon lepturus). Phylogenetic, biological (age), ecological (diet) and geographical (breeding location) factors influencing mercury levels in feathers were investigated. The results were discussed in the light of the bio- and ecological specificities of each species to reveal information on their dietary habits. The tropical zone of the Indian Ocean houses very little anthropogenic activity. It is suspected that this situation may result in lower mercury levels in the avian top predators inhabiting this oceanic area in comparison with those found in temperate oceans, and perhaps in other tropical waters under anthropogenic influences. Mercury levels determined in these six seabirds were thus compared with mercury in feathers of marine birds originating from other areas worldwide.

\section{Materials and methods}

\subsection{Study sites}

The seabirds studied during this investigation originated from colonies established across the western Indian Ocean. The following islands were chosen in the intention of giving a representative overview of the region (Figure 1): Bird Island in Seychelles $\left(4^{\circ} 53^{\prime} S, 55^{\circ} 12^{\prime} \mathrm{E}\right)$, Lys Island which is part of the Glorioso

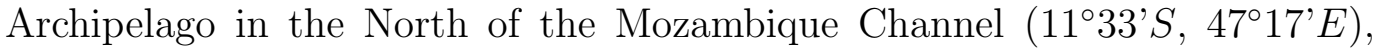
Juan de Nova which is located in the center of the Mozambique Channel $\left(17^{\circ} 03^{\prime} S, 42^{\circ} 45^{\prime} E\right)$, Europa, located in the southern part of the Mozambique Channel $\left(22^{\circ} 20^{\prime} S, 40^{\circ} 22^{\prime} E\right)$ and Reunion Island $\left(21^{\circ} 07^{\prime} S, 55^{\circ} 33^{\prime} E\right)$. 


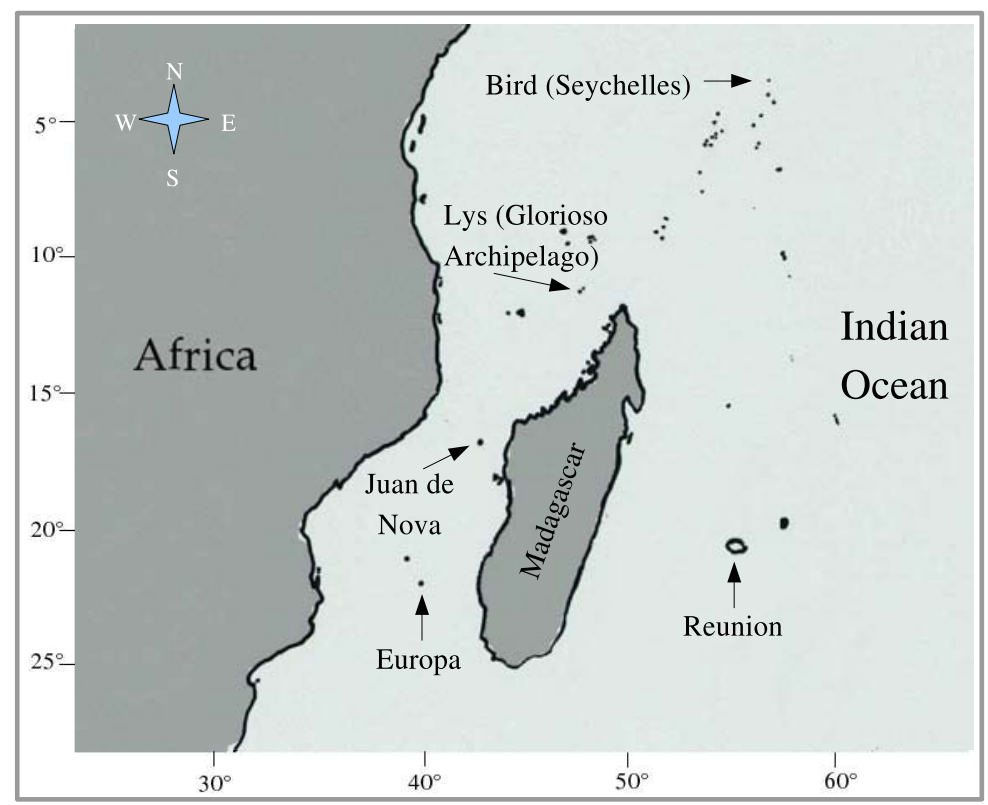

Fig. 1. Map of the study sites (western Indian Ocean).

\subsection{Studied seabirds}

The main morphological and biological characteristics of the studied species are presented in Table 1 and in the following sections.

Table 1

Morphological and biological characteristics of seabirds breeding on islands of the south-western Indian Ocean (Schreiber \& Burger 2001, Schreiber et al. 2002, Ramos \& Pacheco 2003, Surman \& Wooler 2003, Le Corre pers. observ.). Data given for specific islands correspond to measures originating from this study.

\begin{tabular}{|c|c|c|c|c|c|c|}
\hline & $\begin{array}{l}\text { Sooty } \\
\text { Tern }\end{array}$ & $\begin{array}{c}\text { Brown } \\
\text { Noddy }\end{array}$ & $\begin{array}{l}\text { Lesser } \\
\text { Noddy }\end{array}$ & $\begin{array}{l}\text { Audubon's } \\
\text { Shearwater }\end{array}$ & $\begin{array}{l}\text { Barau's } \\
\text { Petrel }\end{array}$ & $\begin{array}{l}\text { White-tailed } \\
\text { Tropicbird }\end{array}$ \\
\hline Lifespan (maximum age in years) & 36 & 27 & 25 & $>20$ & $>25$ & $>16-20$ \\
\hline Age of sexual maturity (years) & $4-10$ & $2-6$ & $2-5$ & $2-5$ & $5-6(?)$ & $3-4$ \\
\hline Mean weight of adults ( $g$ ) & $\begin{array}{l}\text { mean } \pm \text { SD } \\
\mathrm{n}\end{array}$ & & & & & \\
\hline Europa Island & $\begin{array}{l}220 \pm 14 \\
42\end{array}$ & - & - & - & - & - \\
\hline Juan de Nova Island & $\begin{array}{l}205 \pm 24 \\
16\end{array}$ & - & - & - & - & - \\
\hline Lys Island & $\begin{array}{l}177 \pm 20 \\
16\end{array}$ & $\begin{array}{l}178 \pm 27 \\
3\end{array}$ & $\begin{array}{l}89 \pm 7 \\
21\end{array}$ & - & - & - \\
\hline Reunion Island & - & $\begin{array}{c}126 \pm 22 \\
17\end{array}$ & - & $\begin{array}{l}196 \pm 59 \\
23\end{array}$ & $\begin{array}{l}306 \pm 33 \\
21\end{array}$ & $\begin{array}{l}276 \pm 50 \\
32\end{array}$ \\
\hline Bird Island & $\begin{array}{l}188 \pm 22 \\
13\end{array}$ & - & - & - & - & - \\
\hline Wingspan of adults $(\mathrm{cm})$ Worldwide data & $82-94$ & $75-86$ & $58-63$ & $64-74$ & 96 & $90-95$ \\
\hline
\end{tabular}




\subsubsection{Geographical distribution and breeding patterns}

The Sooty Tern, a widely scattered pan-tropical seabird, is the most numerous of the six species with nearly 6 million pairs living in the western Indian Ocean where they breed on various islands: Cosmoledo, Europa, Glorioso, Juan de Nova, Madagascar, Mauritius, Rodrigues, Seychelles and Zanzibar (Schreiber et al., 2002; Le Corre and Jaquemet, 2005; Feare et al., in press). They breed synchronously in very large colonies although breeding seasons vary among islands (in austral winter at Europa and Seychelles, in austral summer at Juan de Nova), and among years (on Lys Island for example) (Le Corre, 2001). The Brown Noddy and the White-tailed Tropicbird are also widely distributed throughout tropical oceans and breed on numerous islands of the Indian Ocean. Both are asynchronous breeders although Brown Noddies are fairly synchronous in Seychelles. The synchronous Lesser Noddy is present in Australia, and breeds extralimitally in the tropical Indian Ocean in Rodrigues, Seychelles, Saint Brandon (Mauritius), the Chagos Archipelago, and the Maldives (Higgins and Davies, 1996). Audubon's Shearwater is also asynchronous, and is found in the Indian Ocean (Comoros, Europa, Mayotte, Reunion and Seychelles), the western Pacific around the Galapagos Islands, as well as in the Antilles, the Bahamas and the Caribbean. However, the birds considered in this study belong to the subspecies $P$. l. bailloni which is known to breed only on Reunion and Europa islands (Le Corre, 2000). The least widespread of these seabirds is Barau's Petrel which is endemic of Reunion, where its population is estimated at 4000 to 6500 pairs, with a breeding season extending from November to May (Le Corre et al., 2001).

\subsubsection{Diet}

Diet composition of the studied species is known only for the breeding period from stomach content of adults and chicks.

In Seychelles, Sooty Terns eat mostly goatfish and squid (Ramos 2000, pers. comm.). In Reunion, stomach content analysis indicates that the diet of Audubon Shearwaters is composed of $50 \%$ squid (mainly Sthenoteuthis oualaniensis) and $50 \%$ fish, that Barau's Petrel is mostly squid-eating, with $98 \%$ squid ( $S$. oualaniensis and Taonius sp.) and $2 \%$ fish and that the White-tailed Tropicbird eats $80 \%$ squid (mainly S. oualaniensis) and 20\% fish (Mollidae and Dactylopteridae) (Le Corre, unpubl. data). The local dietary prey composition of the two Noddies is not known. In the Mozambique Channel, Sooty Terns generally prey on fish of the following families: Carangidae, Exocoetidae, Hemiramphidae, Scombridae and Sphyraenidae (Jaquemet et al, in prep.). All squids consumed belong to the Ommastrephidae family with the dominant species being S. oualaniensis. More specifically, Sooty Terns from Europa mainly feed on flying squids and juveniles of epi-pelagic and meso-pelagic 
fishes. At Juan de Nova, Sooty Terns mostly consume small fish and especially larvae of coastal Mullidae and Engraulidae. On Lys Island, their diet is composed of flying squids, juveniles and larvae of epi-pelagic fish, and larvae of reef fish (Jaquemet et al, pers. com.). The diet of the two Noddies from Lys Island is unknown.

\subsection{Bird sampling}

Feather sampling was conducted in 2004 on each island except for Reunion Island where the sampling effort extended from 2001 to 2004. Sampling acts were conducted in colonies, during the species' breeding period, except for the Lesser Noddies which were sampled at night while non-breeders were roosting on Lys Island. The number of birds sampled on each island is given in Table 2 . Breast feathers were collected on live birds caught on the ground with a net, or on birds which died from accidental causes, i.e. on healthy birds. Because of their spontaneous attraction to light, petrels and shearwaters often die from fatal collisions with urban light sources. This is particularly frequent in Reunion Island (Le Corre et al., 2001) where bird colonies are situated mostly inland forcing birds to fly over a considerably urbanized coastline. Simultaneously to the feather sampling, each individual was assigned to one of two age-classes, juvenile or adult, on the basis of beak and plumage features.

\subsection{Sample preparation and mercury analysis}

Pectoral feathers were washed vigorously in two series of triple baths of $0.25 \mathrm{~N}$ sodium hydroxide solution alternated with triple baths of deionized water, and dried for $24 h$ at $50^{\circ} \mathrm{C}$ in order to remove adherent external deposits and airborne contamination (Walsh, 1990; Burger, 2001) which could alter the results of the analysis of mercury sequestrated in the feathers. Thereby, the existence of external mercury contamination was substantiated by the comparison of mercury levels in 10 feather samples of which one aliquot was washed according to the latter protocol and the second aliquot was simply agitated in deionized water. The results showed significantly higher mercury levels in the second aliquots (by 1.6 to 5.9 fold) in comparison with the aliquots washed in sodium hydroxide $(t-t e s t: p<0.001)$.

Total mercury analyses were carried out with an Advanced Mercury Analyzer (ALTEC AMA 254) on aliquots ranging from 5 to $20 \mathrm{mg}$ of dried sample weighed to the nearest $0.01 \mathrm{mg}$. The detection limit, accuracy and reproducibility of the preparation were tested by preparing replicates of lobster hepatopancreas (TORT-2) reference standards (National Research Council, 
Canada) and blanks along with each set of samples. The detection limit, determined as $3 \times$ the value of at least 8 blanks, was equal to $2.5 \mathrm{ng} \cdot \mathrm{g}^{-1}$. Accuracy (mean $\pm \mathrm{SD}$ ) was estimated as the closeness of each measured value to the certified value of TORT-2 $\left(0.27 \pm 0.06 \mu g . g^{-1}\right)$; measured values were always within $6 \%$ of this reference value. Reproducibility was estimated as the closeness of replicate measurements: the coefficient of variation given by relative standard deviations was always lower than $20 \%$. Mercury levels are expressed in $\mu g \cdot g^{-1}$ of dry weight (d.w.).

\subsection{Interpretation of plumage mercury levels}

Most adult seabirds undergo molt at sea during the non-breeding season (Cramp, 1977). As there is no documentation on the molting processes of the studied species in the western Indian Ocean and as no molting adult was found in the colonies, we have assumed here that they all molt during the non-breeding season. As mercury levels in feathers correspond to part of the dietary input since the last molt, their analysis in breast feathers of juvenile birds reflects the dietary mercury intake since hatching, and are thus indicators of the bioavailable mercury in prey present in the water masses in which adults forage to feed their young. On the contrary, the breast feathers collected on adults present on the island during the breeding period were grown while the bird was at sea. The mercury levels in these feathers testify of the mercury availability in the waters adults fed from during the non-breeding season.

\subsection{Statistical analysis}

Statistical analyses were performed using the GNU R statistical system (R Development Core Team, 2005). All statistical samples submitted to tests were first checked for normality by means of Shapiro-Wilk test. In all cases, nonparametric tests were used as mercury values did not follow Gaussian trends. The influence of species and location on mercury levels was tested by means of Kruskal-Wallis $(K W)$ test followed, in case of significant differences, by multiple pairwise comparison Wilcoxon $(W)$ test. Wilcoxon tests were also applied to test the influence of age classes on mercury levels. Levels of significance of these tests were divided into classes of $p$-values $(N S \geq 0.05 ; *<0.05$; $* *<0.01 ; * * *<0.001$ ), with standard deviation (SD), sample size (n) and coefficient of variation (CV) indicated. 


\section{Results}

Feather mercury levels for each species $\mathrm{x}$ age $\mathrm{x}$ location subgroup are presented in Table 2. All samples were above the method detection limit. The highest mean mercury level was noted in adult Barau's Petrels from Reunion Island and the lowest in juvenile Sooty Terns from Lys Island in the Glorioso Archipelago (19 times lower). These large differences in mercury impregnation across subgroups testify of the influence of age, species and location on the plumage mercury levels of these seabirds.

Table 2

Mercury levels (Mean $\left.\pm \mathrm{SD}, \mu g \cdot g^{-1} d . w.\right)$, inter-specific and inter-locational comparison results in feathers of juvenile and adult seabirds from islands of the southwestern Indian Ocean.

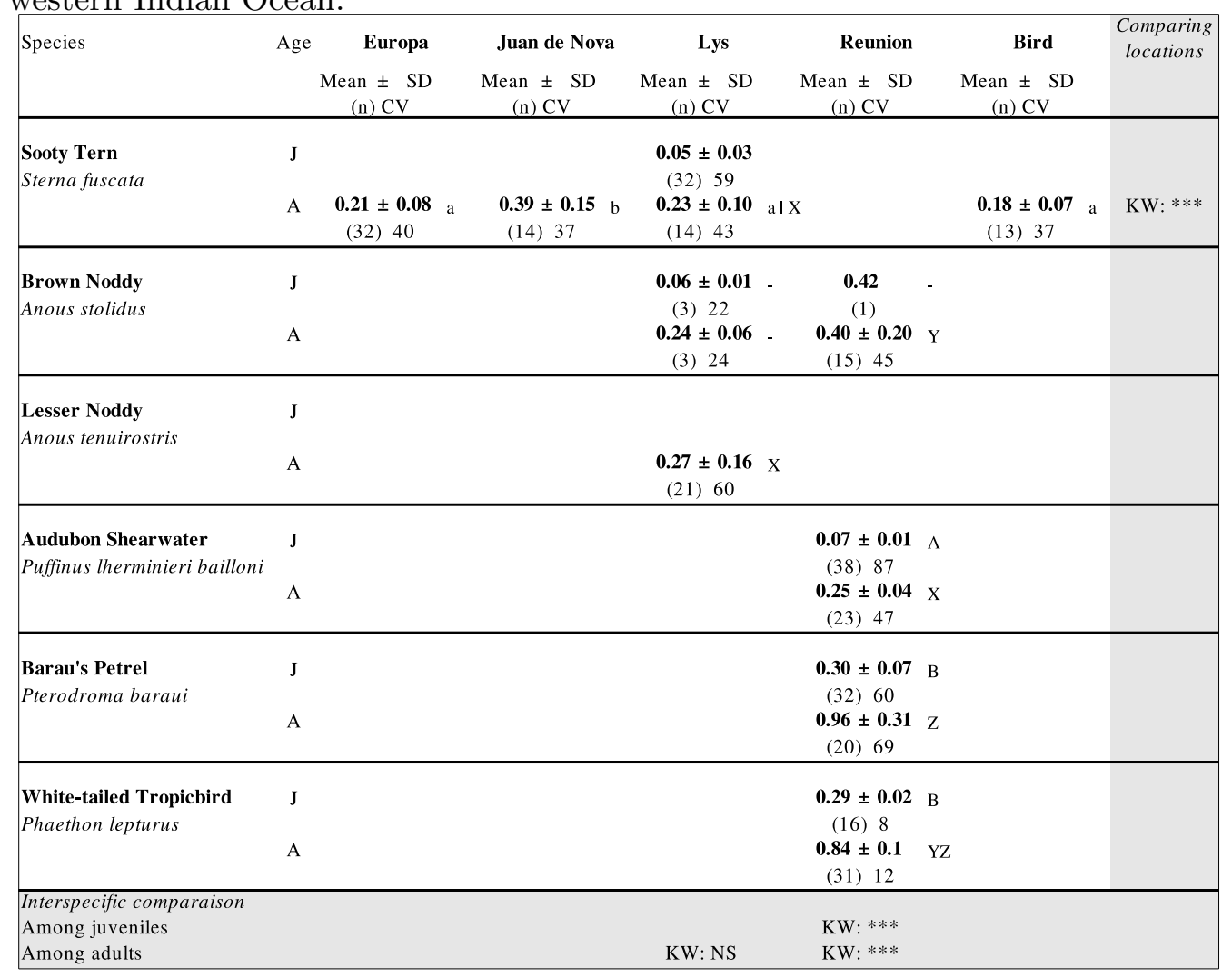

For adult Sooty Terns, the significance of the mercury level differences among locations is given in the last column. KW: Kruskal-Wallis. The letters $\mathrm{a}$ and $\mathrm{b}$ are used to indicate which subgroups differ: subgroups sharing the same letter do not differ significantly. The significance of the mercury level differences among juveniles, respectively adults, of the different species are given in the two bottom lines using the letters $\mathrm{A}$ and $\mathrm{B}$, respectively $\mathrm{X}, \mathrm{Y}$ and $\mathrm{Z}$ to indicate which subgroups differ. Subgroups containing too few values to be included in hypotheses tests are marked with the following symbol: -. 


\subsection{Age-class mercury levels}

The influence of age on mercury level in the feathers was tested on 4 of the 6 species. Age-class comparisons were conducted for the islands of Lys and Reunion separately (Figure 2). Adult:juvenile mercury ratios were similar among species from the same study site, and slightly different between islands: 3.6, 3.2 and 2.9 for Audubon Shearwater, Barau's Petrel and White-tailed Tropicbird respectively in Reunion, and 4.6 and 4.0 for Sooty Tern and Brown Noddy respectively in Lys.
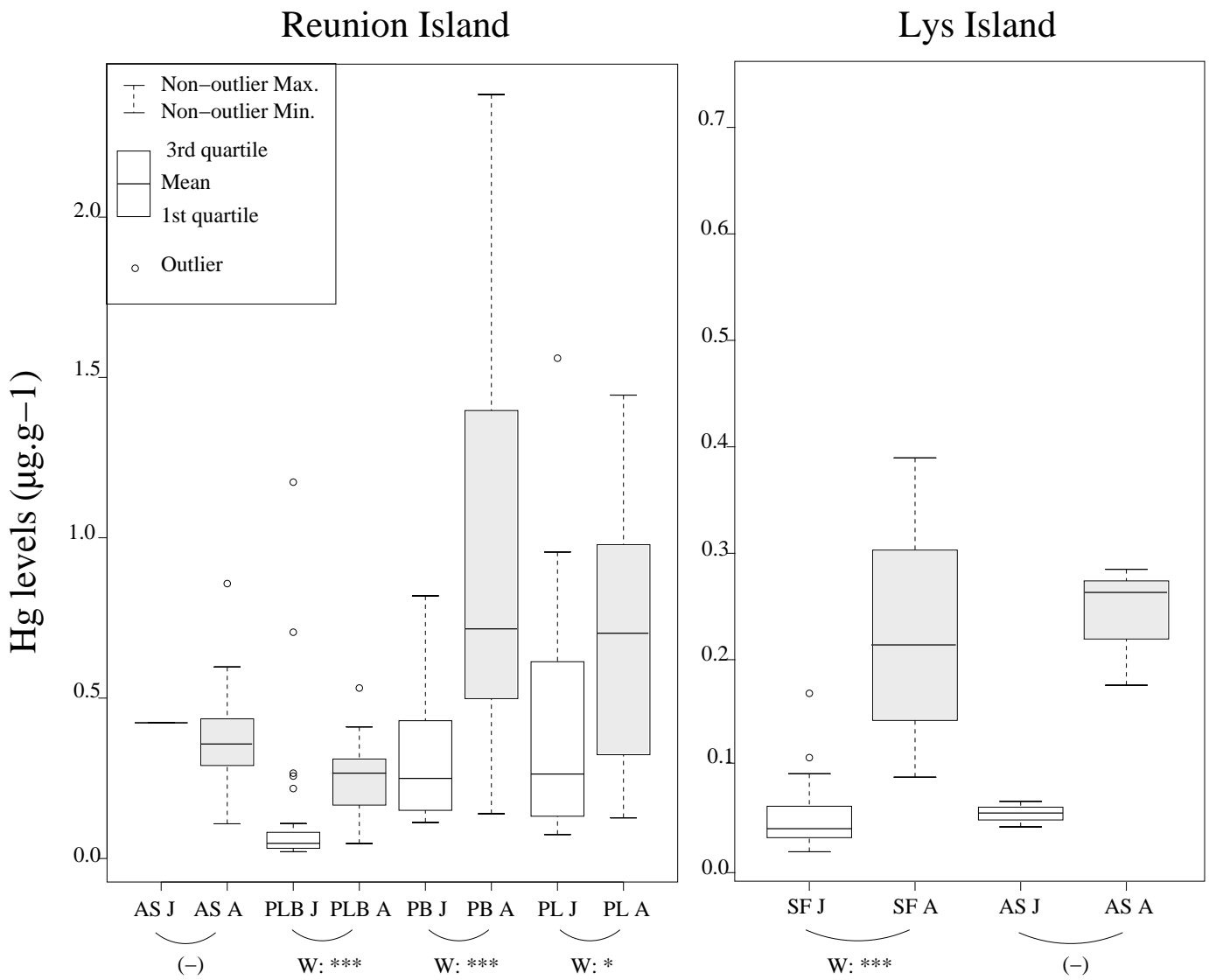

Fig. 2. Comparison of mercury levels $\left(\mu g . g^{-1}\right.$ d.w.) in feathers of juvenile $(\mathrm{J})$ and adult (A) seabirds. AS: Anous stolidus; PLB: Puffinus lherminieri bailloni; PB: Pterodroma baraui; PL: Phaethon lepturus; SF: Sterna fuscata. The significances of the level differences between juveniles and adults are indicated below the boxplots. Significances were not given when at least one of the tested subgroups had too few values (-).

\subsection{Species related differences within sites}

On Lys, there were no significant differences in feather mercury levels among adult Brown Noddies, Lesser Noddies and Sooty Terns (Table 2). On Reunion 
Island, Barau's Petrels and White-tailed Tropicbirds had significantly $(p<$ 0.001) higher mercury levels than Audubon Shearwaters in both, juveniles and adults. Adult Brown Noddies had significantly $(p=0.023)$ higher levels of mercury than adult Audubon Shearwaters and significantly $(p=0.014)$ lower levels than adult petrels.

\subsection{Geographical mercury patterns}

Plumage mercury levels were significantly higher in adult Sooty Terns from Juan de Nova than in those breeding on Europa $(p=0.001)$, Lys $(p=0.012)$ or Bird islands $(p=0.001)$ (Table 2$)$. Differences among the later islands were not significant. From the few results obtained for Brown Noddies, seabirds breeding on Reunion Island seem to be subject to higher mercury exposure than those breeding on Lys Island (Table 2).

\section{Discussion}

\subsection{Comparison with other species and areas}

In Table 3, feather mercury levels in seabirds from this study are compared to the same, or phylogenically related species from other locations in the world. Elemental levels in juveniles and adults are presented separately.

Worldwide, mercury in tern feathers covers a large range of levels generally between 0.10 and $12 \mu \mathrm{g} \cdot \mathrm{g}^{-1}$ d.w. (Burger and Gochfeld, 1997). Mean mercury levels in adult terns from the western Indian Ocean (this study) were close to the lower limit of this range of values. Moreover, they were lower than levels reported for the same tern species from the Pacific and Atlantic Oceans, and those measured in Bridled Tern, Roseate Tern, Common Tern, Arctic Tern and Black Noddy originating from tropical, temperate and arctic environments (Table 3).

Procellariiformes are known to concentrate much higher elemental levels than many other seabirds, with burdens leveling off at $24 \mu g . g^{-1}$ wet weight (w.w.) in the Southern Indian Ocean White-chinned Petrel for example (Kim et al., 1996b). Adult Barau's Petrels had the highest mean mercury levels among the studied species with $0.96 \mu g . g^{-1} d . w$. It, nonetheless, fitted in the 0.6$2.7 \mu g . g^{-1}$ d.w. range previously reported for other Petrels and Shearwaters (Burger and Gochfeld, 1997). In fact, Barau's Petrels had much lower mercury levels than other petrel species of equivalent or smaller sizes originating from 
Table 3

Mercury levels (Mean $\pm \mathrm{SD}, \mu g . g^{-1}$ ) in seabird feathers.

\begin{tabular}{|c|c|c|c|c|c|c|}
\hline \multirow[t]{2}{*}{ Species } & \multirow[t]{2}{*}{ Origin } & \multicolumn{2}{|r|}{ Juveniles } & \multicolumn{2}{|r|}{ Adults } & \multirow{2}{*}{ References } \\
\hline & & (n) & & (n) & & \\
\hline \multicolumn{7}{|l|}{ Terns: } \\
\hline Sooty Tern & Europa Island & & & $(32)$ & $0.21 \pm 0.08$ & This study \\
\hline \multirow[t]{6}{*}{ Sterna fuscata } & Juan de Nova Island & & & (14) & $0.39 \pm 0.15$ & This study \\
\hline & Glorioso Archipelago & $(32)$ & $0.05 \pm 0.03$ & $(14)$ & $0.23 \pm 0.10$ & This study \\
\hline & Seychelles & & & (37) & $0.18 \pm 0.07$ & This study \\
\hline & Hawaiian Islands & (16) & $0.16 \pm 0.02$ & $(26)$ & $1.04 \pm 0.92$ & Burger and Gochfeld (2001) \\
\hline & Great Barrier Reef & & & $(15)$ & $0.44 \pm 0.18$ & Burger and Gochfeld (1991) \\
\hline & Puerto Rico & & & $(15)$ & $2.64 \pm 0.31$ & Burger and Gochfeld (1991) \\
\hline Bridled Tern & Puerto Rico & & & $(15)$ & $1.36 \pm 0.35$ & Burger and Gochfeld (1991) \\
\hline \multicolumn{7}{|l|}{ Sterna anaethetus } \\
\hline Roseate Tern & Puerto Rico & & & $(15)$ & $2.24 \pm 0.31$ & Burger and Gochfeld (1991) \\
\hline \multicolumn{7}{|l|}{ Sterna dougallii } \\
\hline Common Tern & NW Mediterranean & & & (5) & 0.92 & Arcos et al. $(2002)^{\Delta}$ \\
\hline \multicolumn{7}{|l|}{ Sterna hirundo } \\
\hline Arctic Tern & Northeast Siberia & & & (5) & $0.90 \pm 0.10$ & Kim et al. (1996a) ${ }^{\ddagger}$ \\
\hline \multicolumn{7}{|l|}{ Sterna paradisaea } \\
\hline Brown Noddy & Glorioso Archipelago & (3) & $0.06 \pm 0.01$ & (3) & $0.24 \pm 0.06$ & This study \\
\hline \multirow[t]{4}{*}{ Anous stolidus } & Reunion Island & (1) & 0.42 & $(15)$ & $0.40 \pm 0.20$ & This study \\
\hline & Hawaian Islands & & & (8) & $0.70 \pm 0.14$ & Burger and Gochfeld (2000) \\
\hline & Great Barrier Reef & & & $(>12)$ & $0.85 \pm 0.25$ & Burger and Gochfeld (1991) \\
\hline & Puerto Rico & & & $(>12)$ & $1.49 \pm 0.77$ & Burger and Gochfeld (1991) \\
\hline Lesser Noddy & Glorioso Archipelago & & & $(21)$ & $0.27 \pm 0.16$ & This study \\
\hline Anous tenuirostris & & & & & & \\
\hline Black Noddy & Puerto Rico & & & $(15)$ & $1.55 \pm 0.29$ & Burger and Gochfeld (1991) \\
\hline \multicolumn{7}{|l|}{ Anous minutus } \\
\hline \multicolumn{7}{|l|}{ Shearwaters: } \\
\hline Audubon Shearwater & Reunion Island & $(38)$ & $0.07 \pm 0.01$ & $(23)$ & $0.25 \pm 0.04$ & This study \\
\hline \multicolumn{7}{|l|}{ Puffinus lherminieri bailloni } \\
\hline Wedge-tailed Shearwater & Hawaiian Islands & & & $(27)$ & $2.98 \pm 0.28$ & Gochfeld et al. (1999) \\
\hline Puffinus pacificus & & & & & & \\
\hline Christmas Shearwater & Hawaiian Islands & (9) & $0.34 \pm 0.00$ & (2) & $0.04 \pm 0.11$ & Gochfeld et al. (1999) \\
\hline \multicolumn{7}{|l|}{ Puffinus nativitatis } \\
\hline Pink-footed Shearwater & Chilean Coast & & & $(12)$ & $2.00 \pm 0.20$ & Ochoa-acuña et al. (2002) ${ }^{\Delta}$ \\
\hline \multicolumn{7}{|l|}{ Puffinus creatopus } \\
\hline Sooty Shearwater & Chilean Coast & & & (6) & $1.90 \pm 0.30$ & Ochoa-acuña et al. (2002) ${ }^{\Delta}$ \\
\hline \multicolumn{7}{|l|}{ Puffinus griseus } \\
\hline Little Shearwater & Azores & & & $(82)$ & $3.10 \pm 0.10$ & Monteiro et al. (1998) ${ }^{*}$ \\
\hline \multicolumn{7}{|l|}{ Puffinus assimilis } \\
\hline Petrels: & & & & & & \\
\hline $\begin{array}{l}\text { Barau's Petrel } \\
\text { Pterodroma baraui }\end{array}$ & Reunion Island & $(32)$ & $0.3 \pm 0.07$ & $(20)$ & $0.96 \pm 0.31$ & This study \\
\hline Bonin Petrel & Hawaiian Islands & $(20)$ & $3.87 \pm 0.31$ & $(27)$ & $19.7 \pm 1.1$ & Gochfeld et al. (1999) \\
\hline Pterodroma hypoleuca & & & & & & \\
\hline $\begin{array}{l}\text { Juan Fernández's Petrel } \\
\text { Pterodroma externa }\end{array}$ & Chilean Coast & & & $(11)$ & $3.90 \pm 0.20$ & Ochoa-acuña et al. (2002) ${ }^{\Delta}$ \\
\hline Kermadec Petrel & Chilean Coast & & & (2) & 12 & Ochoa-acuña et al. (2002) ${ }^{\Delta}$ \\
\hline Pterodroma neglecta & & & & & & \\
\hline White-chinned Petrel & Southern Indian Ocean & & & (2) & 24.0 & Kim et al. (1998) $\ddagger \Delta$ \\
\hline Procellaria aequinoctialis & & & & & & \\
\hline Tropicbirds: & & & & & & \\
\hline $\begin{array}{l}\text { White-tailed Tropicbird } \\
\text { Phaeton lepturus }\end{array}$ & Reunion Island & (16) & $0.29 \pm 0.02$ & $(31)$ & $0.84 \pm 0.10$ & This study \\
\hline Red-tailed Tropicbird & Hawaiian Islands & (12) & $2.51 \pm 0.28$ & $(23)$ & $6.41 \pm 0.53$ & Burger and Gochfeld (2000) \\
\hline Phaethon rubricauda & & & & & & \\
\hline
\end{tabular}

* : Hg expressed on wet weight basis

${ }^{*}: \mathrm{Hg}$ analyzed in primary number 5 ; other values correspond to breast feathers

$\Delta:$ Studies for which the protocol did not mention whether the feathers were cleaned for external contaminants. 
other oceans (Gochfeld et al., 1999; na et al., 2002). Mean mercury levels in adult Audubon Shearwaters were also below most reported values (Table 3).

The Phaethon genus has received very limited attention regarding elemental bioaccumulation. Feather mercury levels in White-tailed Tropicbirds from Reunion were more than seven times lower than those found in Red-Tailed Tropicbirds from Midway Island (Burger and Gochfeld, 2000).

Since seabirds are considered as good bioindicators of mercury levels in the marine environment (Furness et al., 1993), the above comparisons of mercury levels in seabird feathers may serve in comparing worldwide environmental mercury levels. The comparison of singles species (or closely related species) from various areas suggests that mercury availability in the western Indian Ocean is low in comparison to other marine environments, including other tropical ecosystems.

Although some of the comparison areas presented above can be considered as relatively enriched in mercury, such as the Mediterranean Sea and some regions of the Atlantic (e.g. the Azores), the recorded values are much lower than levels noted in coastal polluted areas. For example, levels equal to $4.1 \mu g \cdot g^{-1}$ d.w. were noted in Little Egrets sampled in Hong Kong (Connell et al., 2002). Mercury levels in feathers of Herring Gulls from the German North Sea coast showed a peak of $12 \mu \mathrm{g} \cdot \mathrm{g}^{-1} \mathrm{~d}$.w. during the 1940s, presumably due to mercury discharges during the Second World War (Thompson et al., 1993). Also, piscivorious seabirds collected along the shores of the Shiranui Sea, where Minamata disease occurred in the 1960s had mean mercury levels of $7.1 \pm 3.7 \mu g . g^{-1}$ d.w. (Doi et al., 1984). Although laboratory studies that examine mercury levels in feathers associated with behavior, growth, or reproductive abnormalities are scarce, a range of $5-40 \mu g \cdot g^{-1}$ d.w. is considered associated with adverse effects (Burger and Gochfeld, 1997). In this study, the highest mercury level recorded among all birds was more than five times lower than this toxicity level. It can therefore be presumed that the marine birds considered during this work do not suffer from adverse effects of mercury.

\subsection{Age-related differences in mercury levels}

Most studies that examine the differences in mercury levels between adult and juvenile birds report higher levels in adults (e.g. Becker et al., 2002) which substantiates our results. Mercury levels in adults are higher than in young birds because they may eat larger, more contaminated prey, and/or because they have accumulated mercury in their tissues over a longer period of time. Indeed, although feathers act as a route of mercury excretion, a certain percentage of the body burden is not evacuated into the plumage (Lewis and 
Furness, 1991; Kim et al., 1996a) which leads, to some extent, to an increase of mercury with age in some species.

\subsection{Site and species differences in relation to food sources}

Variations in mercury levels between bird species potentially reflect many factors including feeding and migratory habits, body size, life span, molt strategy and taxonomic influences on physiology (Walsh, 1990; Stewart et al., 1999). However, dietary differences have often been proposed as the best explanation of mercury variability (Honda et al., 1990; Fiona et al., 1999) since food is the major intake path in marine vertebrates (Walsh, 1990; Stewart et al., 1999). Detailed information on the diet of pelagic seabirds is scarce as they may be studied only during their breeding season while they are on land. Moreover, feeding habits can change with habitat and season, diminishing the reliability of information obtained by stomach content analysis or foraging observations. Although it is difficult to link observed mercury levels with uptake from the diet without analyzing the potential prey, interspecies differences in plumage mercury levels may offer relative information on the dietary composition.

Tropical seabirds consume a wide variety of prey among which the two major taxonomic groups are fish and squid (Ballance and Pitman, 1999). Fish prey are known to be a source of mercury contamination for top predators because of the high levels they accumulate with time (e.g. Van den Broek et al., 1981; Jaffar and Ashraf, 1988) and because mercury is chiefly under a bioavailable form (Me-Hg) in the muscle tissue (Wagemann et al., 1997). On the other hand, studies on the bioaccumulation of mercury in squid offer conflicting results (McArthur et al., 2003; Seixas et al., 2005). Recent work has however shown that most (70-90\%) of the total mercury in cephalopods is in an organic form (Bustamante et al., 2006). Moreover, squids are considered more as vectors of Cd and Persistent Organic Pollutants (POPs) transfers (Bustamante et al., 1998; Weisbrod et al., 2001). The difference in bioaccumulation potential of these two types of prey may explain part of the difference noted between the mercury-enriched Sooty Terns from Juan de Nova and Sooty Terns breeding on the other three islands. Indeed, according to current knowledge, Sooty Tern diets differ among study sites. Squid constitutes the major dietary resource in Europa and Lys (in reconstituted mass) while fish prey are predominant in Juan de Nova (Section 2.2.2, Jaquemet et al., pers. com.).

It has been demonstrated in previous studies that the inclusion of meso-pelagic prey in seabird diet has an influence on mercury accumulation over and above that of trophic status (Monteiro et al., 1998). More specifically, it has been suggested that the comparatively high mercury levels in Barau's Petrels are due to them feeding on meso-pelagic squids of the Taonius genus (Kojadinovic 
et al., 2007). This supposition relies on the hypothesis that these cephalopods are mercury enriched because they originate from deep, poorly oxygenated waters where mercury is mainly in its organic, more bioavailable form (Monteiro et al., 1998; Thompson et al., 1998). Barau's Petrel is most probably a scavenger (Ballance and Pitman, 1999, Le Corre unpubl. data). Although it has not been observed, Barau's Petrels could also feed on carcasses of larger animals such as marine mammals floating at the water surface. The access to such high trophic level and, consequently, potentially more mercury-enriched food due to mercury biomagnification, could be another source of mercury intake for Barau's Petrels.

Finally, considering that the major internal mercury source in birds is food and that plumage mercury levels differ with prey size, type and origin, coefficient of variation values (Table 2) may be interpreted as the variability of the diet compositions within species $\times$ age-class $\times$ location subgroups. Most $\mathrm{CV}$ values were fairly high, indicating that individuals of the same subgroup have diversified diets. These birds are indeed most likely opportunists as they have little choice of prey in these oligotrophic environments. Sooty Terns require a minimal mass of meal but that the nature of the prey is less important (Jaquemet et al., pers. com.).

\section{Conclusion}

The present work on mercury in the plumage of six seabird species, along with a recent investigation on mercury in pelagic fish (Kojadinovic et al., 2006), suggests that mercury availability in the western Indian Ocean is low in comparison to other marine environments.

The study of the impact of diet on mercury levels is far from simple in tropical species for which trophic relationships are often complex because of the large numbers of prey species available (Ballance and Pitman, 1999). The present investigation has nonetheless enabled us to point out some of the factors influencing mercury intake in the birds considered and obtain clues to certain aspects of their dietary and foraging habits. The investigation of mercury levels of the main prey species of these birds would be useful in pointing out the mercury sources for each seabird, which in turn would help in estimating the importance of each prey in its diet. It would also be of great interest to associate these mercury values to more complete stomach content analysis as well as stable isotope studies to further explore the trophic relationships existing in these seabird communities. 


\section{Acknowledgments}

We acknowledge a grant to J.K. from the Conseil Régional de La Réunion and the European Social Fund. The authors would like to thank S. Jaquemet (University of La Réunion) and the SEOR (Société d'Etudes Ornithologiques de La Réunion) for providing the birds, as well as E. Robert (University of La Réunion) for her help in the field work and in the sample preparation. They also thank J. Ramos and P.C. Tavares for their helpful comments on the biology of seabirds breeding in Seychelles.

\section{References}

Atwell, L., Hobson, K. A., Welch, H. E., 1998. Biomagnification and bioaccumulation of mercury in an arctic marine food web: insights from stable nitrogen isotope analysis. Can. J. Fish. Aquat. Sci. 55, 1114-1121.

Ballance, L. T., Pitman, R. L., 1999. Foraging ecology of tropical seabirds. In: Adams, N. J., Slotow, R. H. (Eds.), Proc. 22 Int. Ornithological Congr. Durban. Johannesburg: Birdlife South Africa, pp. 2057-2071.

Becker, P. H., González-Solís, J., Behrends, B., Croxall, J., 2002. Feather mercury levels in seabirds at South Georgia: influence of trophic position, sex and age. Mar. Ecol. Prog. Ser. 243, 261-269.

Burger, A. E., 2001. Diving depths of shearwaters. Auk 118 (3), 755-759.

Burger, J., 1993. Metals in feathers of brown noddy (Anous stolidus): Evidence for bioaccumulation or exposure levels? Environ. Monit. Assess. 24 (2), 181187.

Burger, J., Gochfeld, M., 1991. Lead, mercury, and cadmium in feathers of tropical terns in Puerto Rico and Australia. Arch. Environ. Contam. Toxicol. 21 (2), 311-315.

Burger, J., Gochfeld, M., 1997. Risk, mercury levels, and birds: relating adverse laboratory effects to field biomonitoring. Environ. Res. 75, 160-172.

Burger, J., Gochfeld, M., 2000. Metal levels in feathers of 12 species of seabirds from Midway Atoll in the northern Pacific Ocean. Sci. Total Environ. 257, $37-52$.

Burger, J., Gochfeld, M., 2001a. Metals in feathers of sooty tern, white tern, gray-backed tern, and brown noddy from islands in the North Pacific. Environ. Monit. Assess. 71, 71-89.

Burger, J., Schreiber, E. A. E., Gochfeld, M., 1992. Lead, cadmium, selenium and mercury in seabird feathers from the tropical mid-Pacific. Environ. Toxicol. Chem. 11, 815-822.

Bustamante, P., Caurant, F., Fowler, S. W., Miramand, P., 1998. Cephalopods 
as a vector of the transfer of cadmium to top marine predators in the NorthEast Atlantic Ocean. Sci. Total Environ. 220, 71-80.

Bustamante, P., Lahaye, V., Durnez, C., Churlaud, C., Caurant, F., 2006. Total and organic $\mathrm{Hg}$ concentrations in cephalopods from the North East Atlantic waters: influence of geographical origin and feeding ecology. Sci. Total Environ. 368 (2-3), 585-596.

Connell, D. W., Wong, B. S. F., Lam, P. K. S., Poon, K. F., Lam, M. H. W., Wu, R. S. S., Richardson, B. J., Yen, Y. F., 2002. Risk to breeding success of Ardeids by contaminants in Hong Kong: evidence from trace metals in feathers. Ecotoxicology 11, 49-59.

Cramp, S., 1977. Handbook of the birds of Europe, the Middle East and North Africa, Vol. 1 Ostrich to ducks. Oxford University Press, Oxford.

Doi, R., Ohno, H., Harad, M., 1984. Mercury in feathers of wild birds from the mercury-polluted area along the shore of the Shiranui Sea, Japan. Sci. Total Environ. 40, 155-167.

Feare, C. J., Jaquemet, S., Le Corre, M., in press. An inventory of Sooty Terns Sterna fuscata in the Western Indian Ocean with special reference to threats and trends. Ostrich .

Fiona, F. M., Phillips, R. A., Bartle, A., Craig, J., Shooter, D., 1999. Influence of phylogeny, diet, moult schedule and sex on heavy metal concentrations in New Zealand Procellariiformes. Mar. Ecol. Prog. Ser. 178, 295-305.

Furness, R. W., Greenwood, J. J. D., Jarvis, P. J., Lehr Brisbin, I., Ormerod, S. J., Tyler, S. J., Montevecchi, W. A., Baillie, S. R., Crick, H. Q. P., Marchant, J. H., Peach, W. J., 1993. Birds as Monitors of Environmental Changes. Chapman and Hall, Cornwall.

Gochfeld, M., Gochfeld, D. J., Minton, D., Murray, B. G., Pyle, P., Seto, N., Smith, D., Burger, J., 1999. Metals in feathers of Bonin Petrels, Christmas Shearwaters, Wedge-tailed Shearwaters and Red-tailed Tropicbird in the Hawaian islands, Northern Pacific. Environ. Monit. Assess. 59, 343-358.

Goede, A. A., De Bruin, M., 1984. The use of bird feather parts as a monitor for metal pollution. Environ. Pollut. 8 (4), 281-298.

Higgins, P. J., Davies, S. J. J. F., 1996. Handbook of Australian, New Zealand and Antartic Birds. Vol. 3. Oxford University Press, Melbourne.

Honda, K., Marcovecchio, J. E., Kan, S., Tatsukawa, R., Osi, H., 1990. Metal concentrations in pelagic seabirds from the north Pacific Ocean. Arch. Environ. Contam. Toxicol 19, 704-711.

Jaffar, M., Ashraf, M., 1988. Selected trace metal concentrations in different tissues of fish from coastal waters of Pakistan (Arabian Sea). Indian J. Mar. Sci. 17, 231-234.

Kim, E. Y., Goto, R., Tanaka, S., Tatsukawa, R., 1998. Distribution of 14 elements in tissues and organs of oceanic seabirds. Arch. Environ. Contam. Toxicol. 33, 638-645.

Kim, E. Y., Murakami, T., Saeki, K., Tatsukawa, R., 1996a. Mercury levels and its chemical form in tissues and organs of seabirds. Arch. Environ. Contam. Toxicol. 30 (2), 259-266. 
Kim, E. Y., Saeki, K., Tanabe, S., Tanaka, S., Tatsukawa, R., 1996b. Specific accumulation of mercury and selenium in seabirds. Environ. Pollut. 95 (3), 261-265.

Kojadinovic, J., Le Corre, M., Cosson, R. P., Bustamante, P., 2007. Trace elements in three marine birds breeding on Reunion Island (Western Indian Ocean) Part 1: Factors influencing their bioaccumulation. Arch. Environ. Contam. Toxicol. 52 (3), 418-430.

Kojadinovic, J., Potier, M., Le Corre, M., Cosson, R. P., Bustamante, P., 2006. Mercury content in commercial pelagic fish and its risk assessment in the Western Indian Ocean. Sci. Total Environ. 366 (2-3), 688-700.

Le Corre, M., 2000. Taxonomic affinities of Audubon's shearwater from Europa Island. Condor 102, 187-190.

Le Corre, M., 2001. Breeding seasons of seabirds at Europa Island (southern Mozambique channel) in relation to seasonal changes in the marine environment. J. Zool. 254, 239-249.

Le Corre, M., Jaquemet, S., 2005. Assessment of the seabird community of the Mozambique Channel and its potential use as an indicator of tuna abundance. Est. Coast. Mar. Sci. 63, 421-428.

Le Corre, M., Ollivier, A., Ribes, S., Jouventin, P., 2001. Light-induced mortality of petrels: a 4-year study from Reunion Island (Indian Ocean). Biol. Conserv. 105, 93-102.

Lewis, S. A., Becker, P. H., Furness, R. W., 1993. Mercury levels in eggs, tissues, and feathers of herring gulls Larus argentatus from the German Wadden Sea Coast. Environ. Pollut. 80 (3), 293-299.

Lewis, S. A., Furness, R. W., 1991. Mercury accumulation and excretion in laboratory reared black-headed gull Larus ridibundus chicks. Arch. Environ. Contam. Toxicol. 21 (2), 316-320.

McArthur, T., Butler, E. C. V., Jackson, G. D., 2003. Mercury in the marine food chain in the Southern Ocean at Macquarie Island: an analysis of a top predator, Patagonian toothfish (Dissostichus eleginoides) and a mid-trophic species, the warty squid (Moroteuthis ingens). Polar Biol. 27 (1), 1-5.

Monteiro, L. R., Costa, V., Furness, R. W., Santos, R. S., 1996. Mercury concentrations in prey fish indicate enhanced bioaccumulation in mesopelagic environments. Mar. Ecol. Prog. Ser. 141, 21-25.

Monteiro, L. R., Granadeiro, J. P., Furness, R. W., 1998. Relationship between mercury levels and diet in Azores seabirds. Mar. Ecol. Prog. Ser. 166, 259265.

na, H. O.-A., Sepúlveda, M. S., Gross, T. S., 2002. Mercury in feathers from Chilean birds: influence of location, feeding strategy, and taxonomic effiliation. Mar. Poll. Bull. 44, 340-349.

R Development Core Team, 2005. R: A language and environment for statistical computing. R Foundation for Statistical Computing, Vienna, Austria. URL http://www.R-project.org

Schreiber, E. A., Feare, C. J., Harrington, B. A., Murray, B. G., Robertson, W. B., Robertson, M. J., Woolfenden, G. E., 2002. Sooty tern. The birds of 
North America 665, 32.

Seixas, S., Bustamante, P., Pierce, G., 2005. Accumulation of mercury in the tissues of the common octopus Octopus vulgaris (L.) in two localities on the Portuguese coast. Sci. Total Environ. 340 (1-3), 113-122.

Stewart, F. M., Phillips, R. A., Bartle, J. A., Craig, J., Shooter, D., 1999. Influence of phylogeny, diet, moult schedule and sex on heavy metal concentrations in New Zealand Procellariiformes. Mar. Ecol. Prog. Ser. 178, 295-305.

Stewart, F. M., Phillips, R. A., Catry, P., Furness, R. W., 1997b. Influence of species, age and diet on mercury concentrations in shetland seabirds. Mar. Ecol. Prog. Ser. 151, 237-244.

Thompson, D. R., Becker, P. H., Furness, R. W., 1993. Long-term changes in mercury concentrations in herring gulls Larus argentatus and common terns Sterna hirundo from the German North Sea coast. Auk 30 (2), 316-320.

Thompson, D. R., Furness, R. W., Monteiro, 1998. Seabirds as biomonitors of mercury inputs to epipelagic and mesopelagic marine food chains. Sci. Total Environ. 213, 299-305.

Van den Broek, W. L. F., Tracey, D. M., Solly, S. R. B., Avrahami, M., 1981. Mercury levels in some New Zealand sea fishes. New Zealand J. Mar. Freshwater Res. 15, 137-146.

Wagemann, R., Trebacz, E., Hunt, R., Boila, G., 1997. Percent methylmercury and organic mercury in tissues of marine mammals and fish using different experimental and calculation methods. Environ. Toxicol. Chem. 16 (9), 1859-1866.

Walsh, P. M., 1990. The use of seabirds as monitors of heavy metals in the marine environment. In: Furness, R., Rainbow, P. (Eds.), Heavy metals in the marine environment. CRC Press, Boca Raton, FL, USA, pp. 183-205.

Weimerskirch, H., Le Corre, M., Jaquemet, S., Marsac, F., 2005a. Foraging strategy of a tropical seabird, the redfooted booby, in a dynamic marine environment. Mar. Ecol. Prog. Ser. 288, 251-261.

Weisbrod, A. V., Shea, D., Moore, M. J., Stegeman, J. J., 2001. Species, tissue and gender-related organochlorine bioaccumulation in white-sided dolphins, pilot whales and their common prey in the Northeast Atlantic. Mar. Environ. Res. 51, 29-50. 